\title{
Synthesis and Applications of Pyridazinones for Base Oil Improvement
}

\author{
S.A. Rizk ${ }^{1}$, S.K. Attia ${ }^{2}$, Doaa I. Osman ${ }^{2}$ and M.I. Nessim ${ }^{2 *}$ \\ ${ }^{1}$ Chemistry Department Department, Faculty of Science, Ain \\ Shams University and ${ }^{2}$ Egyptian Petroleum Research Institute, \\ Evaluation and Analysis Department, Cairo, Egypt.
}

\begin{abstract}
THREE pyridazinone derivatives of the type 4,5dihy dropy ridazin- 3(2H)-ones, N-(4-(6-oxo-5- ((5-pheny 1-1,3,4thiadiazol-2-yl)amino) - 1,4,5,6 - tetrahy dropy ridazin - 3-yl) phenyl) acetamide (4a), 6-(4-chlorophenyl)-4-((5-pheny 1-1,3,4-thiadiazol-2yl)amino)-4,5-di-hydropyridazin-3 (2H)-one (4b) and 6-(4bromophenyl) -4- ((5-phenyl-1,3,4-thiadiazol-2-yl) amino)-4,5dihydropyridazin-3(2H)-one (4c) were synthesized. They were characterized by the conventional tools of analysis, Elemental analysis, IR and ${ }^{1} \mathrm{H}-\mathrm{NMR}$ spectroscopy. The tools of analysis confirmed the structure of the three prepared compounds. These heterocyclic compounds are chemically stable and possess multi actions for base oil improvement. They are tested as antioxidants for local base oil through the change in total acid number (TAN). They gave good results as antioxidants for base oil. Also these three synthesized compounds are tested as corrosion inhibitors for carbon steel in acid medium. The efficiency order for these tested compounds is ranked as follows: $4 \mathrm{a}>4 \mathrm{~b}>4 \mathrm{c}$. Energy of the highest occupied molecular orbital $\left(\mathrm{E}_{\mathrm{HOMO}}\right)$ and lowest unoccupied molecular orbital $\left(\mathrm{E}_{\mathrm{LUMO}}\right)$ for the three prepared compounds were calculated via the $\mathrm{Ab}$ initio method. Studying of the quantum chemical calculations of the synthesized compounds showed good matching with the experimental results.
\end{abstract}

Keywords: Pyridazinones, Imidazole, Thiadiazole, Antioxidant, Anticorrosion, Quantum chemical calculations.

Lubricating oils are subjected to deterioration by oxidation at high temperatures [1]. Antioxidants are the main additives that protect the lubricant from oxidative degradation, and be allowing the oil to meet the challenging supplies for use in industrial applications [2]. In order to see the technical economic and environmental requirements, sulfur and phosphorus content are used in the design of lubricating oil with low concentration $[3,4]$. The compact structure of heterocyclic compounds, lead to possess antioxidant, anticorrosion and anti-wear properties [5-7]. Some functionalized imidazoles and 1,2,4-triazoles are tested as antioxidant additives for industrial lubricating oils [8]. The results explained,

\footnotetext{
*Correspondence: maherni@yahoo.com, Tel.: 01227313378

DOI : 10.21608/ejchem.2017.675.1015

(C) 2017 The National Information \& Documentation Center (NIDOC)
} 
based on correlating the electron donating and withdrawing abilities of the substituents with the oxidation stability.

Otherwise, the aroyl-prop-2-enoic acids have two electrophilic reactions sites. The reactivity of them toward aro matic hydrocarbon, (under Friedel-Crafts condition), and nitrogen nucleophiles, (under Michael addition) were investigated [9-12]. Because of the stability of the intermediate carbocation they behave as $\alpha, \beta$-unsaturated carbonyl rather than $\alpha, \beta$-unsaturated acid. The azaMichael adducts are considered as $\alpha$-a mino acids. They have recognized to show a significant role in the synthes is of novel drug applicants [13-19]. Synthesis of unnatural amino acids is found out cost effective and less time consuming synthetic routes. From this point of view the authors have made an attempt to investigate the reaction of 4-aryl-4-oxo-but-2-enoic acids with 2-amino-1,3,4thiadiazole, under aza-Michael reaction conditions, which produced adducts as $\alpha$-amino acid types with acetic anhydride at different conditions and $\mathrm{N}_{2} \mathrm{H}_{4}$ to give the corresponding furanone, imidazol[2,3-b]1,3,4-thiadiazole, 1,3,4thiadiazo lopyrimidines and pyridazin-one derivatives, respectively. The 2- $(3 H)$ furanone compounds showed important activities as antioxidants. Beside, they are active as antifungal, antibacterial, antiviral, anti-inflammatory, vasodilation, and anticonvulsant [20-25]. Pyridazinone derivatives incorporated with diazole moieties that exhibit biological activity agents, (Emorfazone and related compounds) [26], for therapeutic intervention of renal urologic [27], respiratory (NIP-502) [28] and dermatolog ic diseases (FR-1818177) [29] and pyridazinone, (PDE inhibitor developers) [30]. The design of newly prepared compounds based on the structure containing other biological actives heterocycles on the side chains [31]. In our work we used the prepared compounds as antioxidants and corrosion inhibitors for base oil improvement.

Preparation of additives

\section{Experimental}

All melting points are approximately correcteded and were determined on a Stuart electric melting point apparatus. Elemental analysis was carried out at the Micro analytical Centre, National Research Centre, Giza, Egypt, by El Germany Viro El Microanalys is, IR spectra $(\mathrm{KBr})$ were recorded on infrared spectrometer FT-IR 400D using OMNIC program and are reported frequency of absorptions in terms of $\mathrm{cm}^{-1}$ and ${ }^{1} \mathrm{H}-\mathrm{NMR}$ spectra recorded on a Bruker spectro photometer at $400 \mathrm{MHz}$ using TMS as internal standard and with residual signals of the deuterated solvent $=7.26 \mathrm{ppm}$ for $\mathrm{CDCl}_{3}$ and $2.51 \mathrm{ppm}$ for DMSO- $d_{6} \cdot{ }^{13} \mathrm{C}-\mathrm{NMR}$ spectra were recorded on the same spectrometer at $125 \mathrm{MHz} \mathrm{MHz}$ and referenced to solvent signals $=77 \mathrm{ppm}$ for $\mathrm{CDCl}_{3}$ and $39.50 \mathrm{ppm}$ for DMSO $-d_{6}$. DEPT 135 NMR spectroscopy were used where appropriate to aid the assignment of signals in the ${ }^{1} \mathrm{H}$ and ${ }^{13} \mathrm{C}$-NMR spectra. The mass spectra were recorded on Shimadzu GCMS-QP-1000 EX mass spectrometer at 70 e.v. using the electron ionization technique Homogeneity of all compounds synthesized was checked by TLC.

Egypt. J. Chem. 60, No. 1 (2017) 
Synthesis of the adducts

A solution of 4-ary 1-4-o xo-2-butenoic acids (0.01 mol.) and 5-aryl-2-amino1,3,4-thiadiazole $(0.016 \mathrm{~mol}$. $)$ in $30 \mathrm{ml}$ ethanol was refluxed for $3 \mathrm{~h}$. The crude product was washed by petroleum ether $\left(40-60{ }^{\circ} \mathrm{C}\right)$, and then crystallized from the proper solvent to give the following compounds:

4-(4-Acetylaminophenyl)-4-oxo-2-(5-phenyl-2-thiadiazolylamino) butanoic acid (1a)

Yield $80 \%$, m.p. $160-162{ }^{\circ} \mathrm{C}$, IR for $\mathrm{CO}$ for acid and ketone groups (16951665) $\mathrm{cm}^{-1},{ }^{1} \mathrm{H}-\mathrm{NMR}\left(\mathrm{DMSO}-d_{6}\right) 2.5\left(\mathrm{~s}, 3 \mathrm{H}, \mathrm{CH}_{3} \mathrm{CO}\right), 3.4\left(2 \mathrm{dd}, \mathrm{CH}_{2}-\mathrm{C}=\mathrm{O}\right.$ $J=15.2, \mathrm{~J}=7.7$, diastereotopic protons), 4.2 (dd, $\mathrm{CH}-\mathrm{COOH}$, methine proton), 6.7(s, NH), 7.6-8.1 (m, 9H, Ar-H) , $8.2(\mathrm{~s}, 1 \mathrm{H}, \mathrm{COOH}), 8.6(\mathrm{~s}, 1 \mathrm{H}, \mathrm{C}=\mathrm{O}-\mathrm{NH})$. ${ }^{13} \mathrm{C}$ NMR (125 MHz, DMSO-d $\left.)_{6}\right), \delta 22.3\left(\mathrm{CH}_{3}\right), 48.1 \quad\left(\underline{\mathrm{CH}}_{2} \mathrm{COAr}\right), 72.3$ ( $\underline{\mathrm{CHCOO}}), 108\left(\mathrm{C}_{1} \mathrm{Ar}\right), 114.5120 .3\left(\mathrm{C}_{4} \mathrm{Ph}\right), 123.2\left(\mathrm{C}_{2,6} \mathrm{Ph}\right), 127.2\left(\mathrm{C}_{3,5} \mathrm{Ph}\right), 130.4$ $\left(\mathrm{C}_{1} \mathrm{Ph}\right), 132.1\left(\mathrm{C}_{3,5} \mathrm{Ar}\right), 136.3\left(\mathrm{C}_{2,6} \mathrm{Ar}\right), 143.2\left(\mathrm{C}_{4} \mathrm{Ar}\right), 156.2(\mathrm{SC}=\mathrm{N}), 168.2$ $(\mathrm{CONH}), 171.2(\mathrm{NHC}=\mathrm{N}), 173.5(\mathrm{COO}), 190.30(\mathrm{CO}-\mathrm{Ar}) . \mathrm{MS}: m / z 410\left(\mathrm{M}^{+}\right)$. Anal. Calc. for $\left(\mathrm{C}_{20} \mathrm{H}_{18} \mathrm{~N}_{4} \mathrm{O}_{4} \mathrm{~S}\right)$ : \% C 58.53, H 4.39, N 13.65, S 7.8; Found: \% C 58.30, H 4.31, N 13.00, S 7.43.

4-(4-Chlorophenyl)-4-oxo-2-(5-phenyl-2-thiadiazolylamino) butanoic acid ( $1 \mathrm{~b}$ )

Yield $80 \%$, m.p. $140-142{ }^{\circ} \mathrm{C}$, IR for CO for acid and ketone groups (1695) $\mathrm{cm}^{-1},{ }^{1} \mathrm{H}-\mathrm{NMR}$ (DMSO-d $\left.{ }_{6}\right) 3.5\left(2 \mathrm{dd}, \mathrm{CH}_{2}-\mathrm{C}=\mathrm{O}, J=15.2, J=7.7\right.$, diastereotopic protons), 4.2 (dd, $\mathrm{CH}-\mathrm{COOH}$, methine proton), 6.7(s, NH), 7.6-8.1 (m, 9H, Ar$\mathrm{H}), 8.2(\mathrm{~s}, 1 \mathrm{H}, \mathrm{COOH})$, EIMS: $m / z, 390\left(\mathrm{M}^{+}+2\right), 387.5\left(\mathrm{M}^{+}\right)$. Anal. Calc. for $\left(\mathrm{C}_{18} \mathrm{H}_{14} \mathrm{~N}_{3} \mathrm{O}_{3} \mathrm{SCl}\right): \% \mathrm{C} 55.22, \mathrm{H}$ 3.64, $\mathrm{N} \mathrm{10.85,} \mathrm{S} \mathrm{8.26,} \mathrm{Cl} \mathrm{9.17;} \mathrm{Found:} \mathrm{\%} \mathrm{C}$ 55.00, H 3.20, N 10.54, S 8.00, Cl 8.87.

4-(4-Bromophenyl)-4-oxo-2-(5-phenyl-2-thiadiazolylamino) butanoic acid (1c) Yield $80 \%$, m.p. $128-130{ }^{\circ} \mathrm{C}$, IR for $\mathrm{CO}$ for acid and ketone groups (1693) $\mathrm{cm}^{-1}$, ${ }^{1} \mathrm{H}-\mathrm{NMR}$ (DMSO- $\left.d_{6}\right) \quad 3.5\left(2 \mathrm{dd}, \mathrm{CH}_{2}-\mathrm{C}=\mathrm{O} \quad J=15.2, J=7.7\right.$, diastereotopic protons ), 4.2 (dd, $\mathrm{CH}-\mathrm{COOH}$, methine proton), 6.7(s, NH), 7.6-8.1 (m, 9H, Ar$\mathrm{H}), 8.2(\mathrm{~s}, 1 \mathrm{H}, \mathrm{COOH})$, EIMS: $m / z 435\left(\mathrm{M}^{+}+2(2)\right), 431\left(\mathrm{M}^{+}\right)$. Anal. Calc. for $\left(\mathrm{C}_{18} \mathrm{H}_{14} \mathrm{BrN}_{3} \mathrm{O}_{3} \mathrm{~S}\right): \%$ C 50.01, H 3.26, Br 18.33, N 9.74, S 7.42; Found: \% C 49.37, H 3.00, Br 18.09, N 9.53, S 7.11.

Synthesis of furanones 2 and imidazothiadiazole derivatives 3

A mixture of la-c $(0.005$ mol.) and acetic anhydride $(9.4 \mathrm{~mL})$ was heated under reflux for $1 \mathrm{~h}$ upon water bath. The solid that separated, on cooling, was fractional crystallized from petroleum ether $\left(80-100{ }^{\circ} \mathrm{C}\right)$ afforded imidazothiadiazoles 3 and from dioxane afforded the furanone derivatives 2 . (2a)

2-(5-Acetylaminophenyl-2-oxo-furan-3-yl)amino-5-phenyl-1,3,4-thiadiazole

Yield 50\%, m.p. $200-202{ }^{\circ} \mathrm{C}$, IR: $v \square \square \mathrm{NH} 3297-3100, \mathrm{CH} 3055-2890$, and $\mathrm{CO}$ at 1767 and $1693 \mathrm{~cm}^{-1}$. ${ }^{1} \mathrm{H}-\mathrm{NMR}$ spectrum (DMSO- $d_{6}$ ) exhibits signals at $\delta$ 
2,1 (s $3 \mathrm{H}, \mathrm{CH}_{3} \mathrm{CO}$ ), 4 (dd, 1H, -CH-NH, $J=8.5$ ), 6.7 (bs, NH), 7.5-7.9 (m, 9H of Ar), $6.9(\mathrm{~d}, 1 \mathrm{H}, \mathrm{CH}$ furanone moiety, $J=8.5), 12.7(\mathrm{~s}, 1 \mathrm{H},-\mathrm{C}=\mathrm{O}-\mathrm{NH})$ acidic protons are exchangeable in $\mathrm{D}_{2} \mathrm{O}$. Elem. Anal. For $\left(\mathrm{C}_{20} \mathrm{H}_{16} \mathrm{~N}_{4} \mathrm{O}_{3} \mathrm{~S}\right)$ M.wt. 392.43: Calc.: \% C 61.21, H 4.11, Cl 9.60, N 14.28, S 8.17; Found \% C 60.40, H 3.87, Cl 9.11, N 13.80, S 7.89 .

2-(5-Chlorophenyl-2-oxo-furan-3-yl)amino-5-phenyl- 1,3,4-thiadiazole (2b) Yield 50\%, m.p. $182-184{ }^{\circ} \mathrm{C}$, IR: $v \square \square \mathrm{CH} 3055-2890$ and $\mathrm{CO}$ at $1772 \mathrm{~cm}^{-1} .{ }^{1} \mathrm{H}-$ NMR spectrum (DMSO- $d_{6}$ ) exh ibits signals at $\delta 4(\mathrm{dd}, 1 \mathrm{H},-\mathrm{CH}-\mathrm{NH}, J=8.5), 6.7$ (bs, $\mathrm{NH}), 7.5-7.9(\mathrm{~m}, 9 \mathrm{H}$ of Ar), $6.9(\mathrm{~d}, 1 \mathrm{H}, \mathrm{CH}$ furanone moiety, $J=8.5)$. Elem. Anal. for $\left(\mathrm{C}_{18} \mathrm{H}_{12} \mathrm{ClN}_{3} \mathrm{O}_{2} \mathrm{~S}\right)$ : Calc.: \% C 58.46, \% H 3.27, \% N 11.36, \% S 8.67; Found \% C 58.20, \% H 3.00, \% N 10.90.8, \% S 8.20.

2-(5-Bromophenyl-2-oxo-furan-3-yl)amino-5-phenyl- 1,3,4-thiadiazole (2c) Yield $50 \%$, m.p. $166-168^{\circ} \mathrm{C}$, IR: $v \square \square \mathrm{CH} 3055-2890 \mathrm{~cm}^{-1}$, and $\mathrm{CO}$ at $1770 \mathrm{~cm}^{-1}$. ${ }^{1} \mathrm{H}-\mathrm{NMR}$ spectrum (DMSO- $d_{6}$ ) exh ibits signals at $\delta 4(\mathrm{dd}, 1 \mathrm{H},-\mathrm{CH}-\mathrm{NH}, J=8.5$ ), 6.7 (bs, NH), 7.5-7.9 (m, 9H of Ar), $6.9(\mathrm{~d}, 1 \mathrm{H}, \mathrm{CH}$ furanone mo iety, $J=8.5) .{ }^{13} \mathrm{C}$ NMR (125 MHz, DMSO-d $\left.d_{6}\right), \delta 71.4$ (ㅌHCOfur), $112.3 \quad\left(\mathrm{C}_{1} \mathrm{Ar}\right), 115.2$ 120.3 $\left(\mathrm{C}_{4} \mathrm{Ph}\right), 126.1\left(\mathrm{C}_{2,6} \mathrm{Ph}\right), 127.3\left(\mathrm{C}_{2,6} \mathrm{Ar}\right), 128.2\left(\mathrm{C}_{3,5} \mathrm{Ph}\right), 129.7\left(\mathrm{C}_{1} \mathrm{Ph}\right), 131.1$ $\left(\mathrm{C}_{3,5} \mathrm{Ar}\right), 139.2\left(\mathrm{C}_{4} \mathrm{Ar}\right), 144.3$ (=CHfur), $149.3(\mathrm{C}$ fur $), 154.2(\mathrm{SC}=\mathrm{N}), 169.5$ (COfur), $170.2(\mathrm{NHC}=\mathrm{N})$. Elem. Anal. for $\left(\mathrm{C}_{18} \mathrm{H}_{13} \mathrm{BrN}_{3} \mathrm{O}_{2} \mathrm{~S}\right)$. $\mathrm{M}$ wt 414: Calc.: $\%$ C 58.20, H 3.80, Br 19.08, N 8.40, S 6.60, Found \% C 58.00, H 3.52, Br 18.87, N 8.11, S 6.23 .

5-(4-Acetylaminobenzoylmethyl) $\quad$-2-phenyl-4 -oxoimidazolo $\quad[2,1-b]-1,3,4$ thiadiazole $(3 a)$

m.p. $130-132^{\circ} \mathrm{C}$, yield $35 \%$, IR: v $\mathrm{C}=\mathrm{O}$ are at 1695 and $1669 \mathrm{~cm}^{-1} .{ }^{1} \mathrm{H}-\mathrm{NMR}$ (DMSO- $\left.d_{6}\right)$ exhibits signals at $3.2\left(\mathrm{~s}, 2 \mathrm{H}, \mathrm{CH}_{3} \mathrm{CO}\right), 3.4\left(2 \mathrm{dd}, \mathrm{CH}_{2}-\mathrm{C}=\mathrm{O}, J=7.7\right)$ (diastereotopic protons), 3.9 (dd, $\mathrm{CH}$-imidazo, methine proton), 7.2-7.7 (m, $9 \mathrm{H}$, ArH), $11.2\left(\mathrm{~s}, 1 \mathrm{H}, \mathrm{NH}\right.$, exchangeable by $\left.\mathrm{D}_{2} \mathrm{O}\right)$. Elem. Anal. For $\left(\mathrm{C}_{20} \mathrm{H}_{16} \mathrm{~N}_{4} \mathrm{O}_{3} \mathrm{~S}\right)$ M.wt. 392: Calc.: \% C 61.21, \% H 4.11, \% N 14.28, \% S 8.17; Found \% C 61.00, $\% \mathrm{H} 3.95, \% \mathrm{~N} 14.00, \% \mathrm{~S}$ 7.92. The EI-MS shows the molecular ion peak at $\mathrm{m} / \mathrm{e} 395,392$ corresponding to $(\mathrm{M}+2)^{+}$and $\left(\mathrm{M}^{+}\right)$respectively.

5-(4-Chlorobenzoylmethyl)-2-phenyl-4-oxoimidazolo [2,1-b]-1,3,4 thiadiazole

m.p. $142-144^{\circ} \mathrm{C}$, yield $35 \%$, IR: $v \mathrm{C}=\mathrm{O}$ are at 1691 and $1668 \mathrm{~cm}^{-1} .{ }^{1} \mathrm{H}-\mathrm{NMR}$ (DMSO- $\left.d_{6}\right)$ exhibits signals at $3.31\left(2 \mathrm{dd}, \mathrm{CH}_{2}-\mathrm{C}=\mathrm{O}, J=7.7\right)$ (diastereotopic protons), 4.11 (dd, $\mathrm{CH}-\mathrm{COOH}$, methine proton), 7.6-7.9 (m, 9H, ArH)). Elem. Anal. for $\left(\mathrm{C}_{18} \mathrm{H}_{12} \mathrm{ClN}_{3} \mathrm{O}_{2} \mathrm{~S}\right) \mathrm{M}$ wt 369.5: Calc.: \% C 58.46, H 3.27, $\mathrm{Cl}$ 9.60, N 11.36, S 8.67; Found \% C 58.20, H 3.00, Cl 9.28, N 10.90.8, S 8.20. The EI-MS shows the mo lecular ion peak at $\mathrm{m} / \mathrm{e} 371,369$ corresponding to $(\mathrm{M}+2)^{+}$and $\left(\mathrm{M}^{+}\right)$ respectively. 

(3c)

5-(4-Bromobenzoylmethyl)-2-phenyl-4-oxoimidazolo [2,1-b]-1,3,4 thiadiazole

m.p. $136-138^{\circ} \mathrm{C}$, yield $35 \%$, IR: $v \mathrm{C}=\mathrm{O}$ are at 1701 and $1672 \mathrm{~cm}^{-1} \cdot{ }^{1} \mathrm{H}-\mathrm{NMR}$ (DMSO- $\left.d_{6}\right)$ exhibits signals at $3.21\left(2 \mathrm{dd}, \mathrm{CH}_{2}-\mathrm{C}=\mathrm{O}, J=7.7\right)$ (diastereotopic protons), 3.95 (dd, $\mathrm{CH}-\mathrm{COOH}$, methine proton), 7.5-7.9 (m, 9H, ArH)). Elem. Anal. for $\left(\mathrm{C}_{18} \mathrm{H}_{13} \mathrm{BrN}_{3} \mathrm{O}_{2} \mathrm{~S}\right)$. M wt 413: Calc.: \% C 58.2, H 3.8, Br 19.08, N 8.4, $\mathrm{S}$ 6.6; Found \% C 58.4, H 3.5, Br 19.67, N 8.1, S 6.2.The EI-MS shows the molecular ion peak at $\mathrm{m} / \mathrm{e} 415,413$ corresponding to $(\mathrm{M}+2)^{+}$and $\left(\mathrm{M}^{+}\right)$ respectively.

Synthesis of pyridazinone derivatives $(4 a-c)$.

An equimolar mixture of $1 \mathrm{a}-\mathrm{c}$ or $2 \mathrm{a}-\mathrm{c}$ and hydrazine hydrate was refluxed in ethanol for $3 \mathrm{~h}$ and the solid separated out was filtered off, dried and crystallized from absolute ethanol.

N-(4-(6-oxo-5-((5-phenyl-1,3,4-thiadiazol-2-yl)amino)-1,4,5,6-tetrahydropyridazin-3yl) phenyl)acetamide $(4 a)$

Yield $75 \%$, IR (KBr) v $\mathrm{C}=\mathrm{O}$ of 1674,1708 and $(\mathrm{NH})$ of $3177 \mathrm{~cm}^{-1} .{ }^{1} \mathrm{H}$ NMR $\left(\mathrm{DMSO}-d_{6}\right): \delta 2.2\left(\mathrm{~s}, 3 \mathrm{H}, \mathrm{CH}_{3}\right), 3.7\left(2 \mathrm{dd}, 2 \mathrm{H}, \mathrm{CH}_{2}-\mathrm{C}=\mathrm{N}\right), 4.2(2 \mathrm{dd}, \mathrm{CH}$, methine proton) 6.7 (s, NH, NH of thiadiazole moiety), 7.43-7.81 (m, 9H, Ar-H), 10.26, 11.59 (brs, 2H, NH of acetamido and pyridazinone moieties). EIMS: $m / z: 406$ $\left(\mathrm{M}^{+}\right)$. Anal. Calcd. $\mathrm{C}_{20} \mathrm{H}_{18} \mathrm{~N}_{6} \mathrm{O}_{2} \mathrm{~S}$ : \% C 59.11, H 4.46, N 20.69, S 7.88; Found: \% C 59. 20, H 4.43, N 20. 10, S 7. 34.

6-(4-Chlorophenyl)-4-((5-phenyl-1,3,4-thiadiazol-2-yl)amino)-4,5

dihydropyridazin $-3(2 \mathrm{H})$-one $(4 b)$

Yield $80 \%$, IR (KBr) v $\mathrm{C}=\mathrm{O}$ of 1708 and $(\mathrm{NH})$ of $3177 \mathrm{~cm}^{-1} .{ }^{1} \mathrm{H}$ NMR (DMSO$\left.d_{6}\right): \delta 3.7\left(2 \mathrm{dd}, 2 \mathrm{H}, \mathrm{CH}_{2}-\mathrm{C}=\mathrm{N}\right), 4.2(2 \mathrm{dd}, \mathrm{CH}$, methine proton) $6.7(\mathrm{~s}, \mathrm{NH}, \mathrm{NH}$ of thiadiazole moiety), 7.43-7.81 (m, 9H, Ar-H), 11.59 (brs, 1H, NH pyridazinone mo ieties). ${ }^{13} \mathrm{C}$ NMR (125 MHz, DMSO-d $\left.d_{6}\right), \delta 54.21\left(\mathrm{CH}_{2}\right.$ py), 71.4 (ㅡㅐCOpy), $121.3\left(\mathrm{C}_{1} \mathrm{Ar}\right), 127.3\left(\mathrm{C}_{4} \mathrm{Ph}\right), 128.1\left(\mathrm{C}_{2,6} \mathrm{Ph}\right), 129.3\left(\mathrm{C}_{2,6} \mathrm{Ar}\right), 129.7$ $\left(\mathrm{C}_{3,5} \mathrm{Ph}\right), 131.7\left(\mathrm{C}_{1} \mathrm{Ph}\right), 132.1\left(\mathrm{C}_{3,5} \mathrm{Ar}\right), 137.2\left(\mathrm{C}_{4} \mathrm{Ar}\right), 147.2(\mathrm{C}$ py), 153.2 $(\mathrm{SC}=\mathrm{N}), 166.5$ (COpy), $170.6(\mathrm{NHC}=\mathrm{N})$. Anal. Calcd. $\mathrm{C}_{18} \mathrm{H}_{14} \mathrm{ClN}_{5} \mathrm{OS} . \mathrm{M}$ wt 383.5: \% C 58.81, H 4.13, Cl 9.25, N 18.25, S 8.34; Found: \% C 58.60, H 4.00, Cl 9.01, N 18.04, S 8.12.

6-(4-Bromophenyl) -4-((5-phenyl $\quad-1,3,4 \quad$-thiadiazol $\quad-2-y l)$ amino $)-4,5$ dihydropyridazin-3(2 H)-one $(4 c)$

Yield $70 \%$, IR $(\mathrm{KBr})$ v $\mathrm{C}=\mathrm{O}$ of 1702 and $(\mathrm{NH})$ of $3132 \mathrm{~cm}^{-1} .{ }^{1} \mathrm{H}$ NMR $\left(\mathrm{DMSO}-d_{6}\right): \delta 3.6\left(2 \mathrm{dd}, 2 \mathrm{H}, \mathrm{CH}_{2}-\mathrm{C}=\mathrm{N}\right), 4.2(2 \mathrm{dd}, \mathrm{CH}$, methine proton) $6.7(\mathrm{~s}$, $\mathrm{NH}, \mathrm{NH}$ of thiadiazole mo iety), 7.43-7.81 (m, 9H, Ar-H), 12.09 (brs, 1H, NH pyridazinone moieties). EIMS: $m / z: 429\left(\mathrm{M}^{+}+2\right), 427\left(\mathrm{M}^{+}\right)$. Anal. Calcd. $\mathrm{C}_{18} \mathrm{H}_{14} \mathrm{BrN}_{5} \mathrm{OS}$ : \% C 57.21, H 3.82, Br 18.50, N 16.39, S 7.49; Found: \% C 57.00, H 3.60, Br 18.24, N 16.13, S 7.19. 
Physicochemical properties of the base stock

The tested base stock was delivered from Co-operative Petroleum Company, Cairo, Egypt. The physicochemical characteristics of the base stock are tabulated in Table 1 , showed that wax content $0.86 \%$, total Sulfur $0.36 \%$, carbon residue $0.75 \%$, total acid number $0.07 \mathrm{mg} \mathrm{KOH} /$ gram sample Viscosity $7.42 \mathrm{cSt}$ at $10{ }^{\circ} \mathrm{C}$, has high flash point $221{ }^{\circ} \mathrm{C}$ and it has low pour point $-3{ }^{\circ} \mathrm{C}$. The oxidation test methods were carried out according to the standard test method ASTM D- 943.

TABLE 1. Base Stock properties.

\begin{tabular}{|c|c|c|}
\hline Test & Result & Standard Test Method \\
\hline Density at $15.56{ }^{\mathrm{O}} \mathrm{C}, \mathrm{g} / \mathrm{cm}^{3}$ & 0.8818 & ASTM D - 1298 \\
\hline Pour Point, ${ }^{\mathrm{O}} \mathrm{C}$ & -3 & ASTM D - 97 \\
\hline $\begin{array}{l}\text { Viscosity at } 40{ }^{\circ} \mathrm{C} \\
\text { at } 100^{\circ} \mathrm{C}\end{array}$ & $\begin{array}{c}52.34 \\
7.42\end{array}$ & ASTM D - 445 \\
\hline Viscosity Index (VI) & 92 & ASTM D - 2270 \\
\hline Total Acid Number (TAN) & 0.07 & ASTM D - 664 \\
\hline Sulfur Content, wt \% & 0.36 & ASTM D - 4294 \\
\hline Color & 2.5 & ASTM D - 1500 \\
\hline Ash Content, wt \% & 0.003 & ASTM D - 482 \\
\hline Copper Corrosion & $1 \mathrm{a}$ & ASTM D - 130 \\
\hline Flash Point, ${ }^{\circ} \mathrm{C}$ & 221 & ASTM D - 92 \\
\hline Aniline Point & 100.6 & ASTM D - 611 \\
\hline
\end{tabular}

\section{Corrosion inhibitor study}

$1.0 \mathrm{M} \mathrm{HCl}$ solution is prepared by dilution of $37 \% \mathrm{HCl} \mathrm{A.R.} \mathrm{grade} \mathrm{with}$ distilled water and the examined inhibitors is $0.025-0.075 \mathrm{mmol} \mathrm{dm}^{-3}$. The composition of carbon steel bar presented in Table 2.

TABLE 2. Carbon steel composition in wt. \%.

\begin{tabular}{|c|c|c|c|c|c|c|c|c|c|c|c|}
\hline Element & $\mathbf{S i}$ & $\mathbf{C}$ & $\mathbf{M n}$ & $\mathbf{P}$ & $\mathbf{S}$ & $\mathbf{C u}$ & $\mathbf{N i}$ & $\mathbf{C r}$ & $\mathbf{A l}$ & $\mathbf{M o}$ & $\mathbf{V}$ \\
\hline (wt.\%) & 0.22 & 0.09 & 1.52 & 0.01 & 0.05 & 0.02 & 0.04 & 0.02 & 0.04 & 0.004 & 0.002 \\
\hline
\end{tabular}

\section{Electrochemical measurements}

Electrochemical measurements are performed with a traditional threeelectrode cell using Volta lab 40 (Tacussel-Radiometer PGZ402) potentiostat controlled by Tacussel corrosion analys is software (model: Voltamaster 4) under static condition. All experiments are performed at $25{ }^{\circ} \mathrm{C}$. Potentiodynamic polarization measurements have been achieved by changing the electrode from -700 to $-400 \mathrm{mV}$ versus SCE. The inhibition efficiency percentage $\left(\eta_{\mathrm{p}} \%\right)$ was calculated using the following equations:

$$
\eta_{\mathrm{p}} \%=\left(1-I / I_{\mathrm{o}}\right) \times 100,
$$

Egypt. J. Chem. 60, No. 1 (2017) 
where $I_{0}$ and $I$ are the corrosion current densities in the absence and presence of the inhibitor, respectively.

\section{Chemistry}

\section{Results and Discussion}

The authors reported the behavior of 4-aryl-4-oxo-but-2-enoic acids (1) that were permitted to react with novel nitrogen nucleophile e.g. 2-amino-5-phenyl1,3,4-thiadiazole in boiling ethanol (neutral medium) afforded the aza-Michael products 4-(4-acetylamino/chloro/bromophenyl)-2-(5-phenyl-1,3,4thiadiazol-2yl) amino-4-oxo-butan-oic acids (1). The 2-aminothiadiazole derivative could be synthesized from treatment of aromatic acid with thiosemicarbazide in the presence of $\mathrm{POCl}_{3}$ under reflux $0.5 \mathrm{~h}$ (Scheme 1).

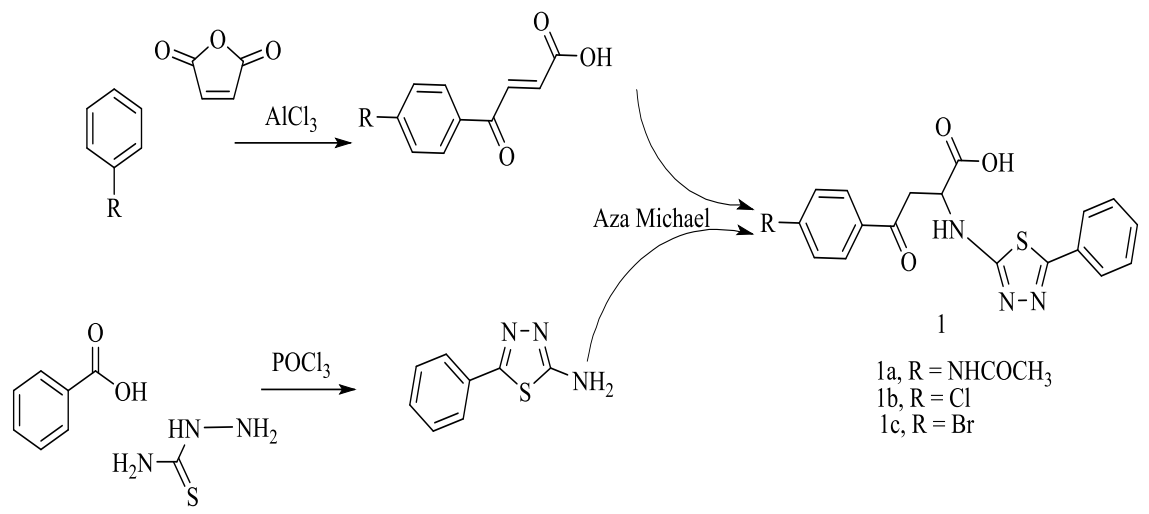

Scheme 1.

The recent efforts made for the development of new ascorbic acid analogues in obtaining antioxidant [16-20], antitumor [21] agents have resulted 2(3H)furanones as a new anti-inflammatory and antioxidant agents [20]. Some 3,5diaryl-2(3H)furanone possess significant anti-inflammatory and antioxidant activities. So, the current work describes the synthes is of $2(3 \mathrm{H})$-furanone with expected anti-antio xidant activity [2,5] yielded the corresponding furanone 2 that is confirmed chemically by interaction with hydrazine hydrate to afford the corresponding pyridazinone 4 (Scheme 2). Moreover, the another product could be isolated imidazolo [2,1-b]1,3,4-thiadiazole derivative. There may be a competitive reaction in dehydration followed by cyclization via route [i] carboxylic group within enol of the aroyl group afford ing the foranone 2 and/or via route[ii] carboxy lic group within imino of the thioguanidino group affording imidazolothiadiazole derivative 3 (Scheme 2).

When the acids 1 and their furanone were submitted to react with hydrazine hydrate in boiling ethanol, afforded pyridazin-3-(2H)one 4 (Scheme 3). It's well-known and found out the important the 6-aryl pyridazin-3(2H)-one in 
medicinal fields [22-28]. The newly route apply and study the target compounds in petro chemistry as antioxidant, and anti-corrosion additives. In addition to study some characterization of substituent group effect upon the active site of pyridazinone nucleus (Scheme 3).

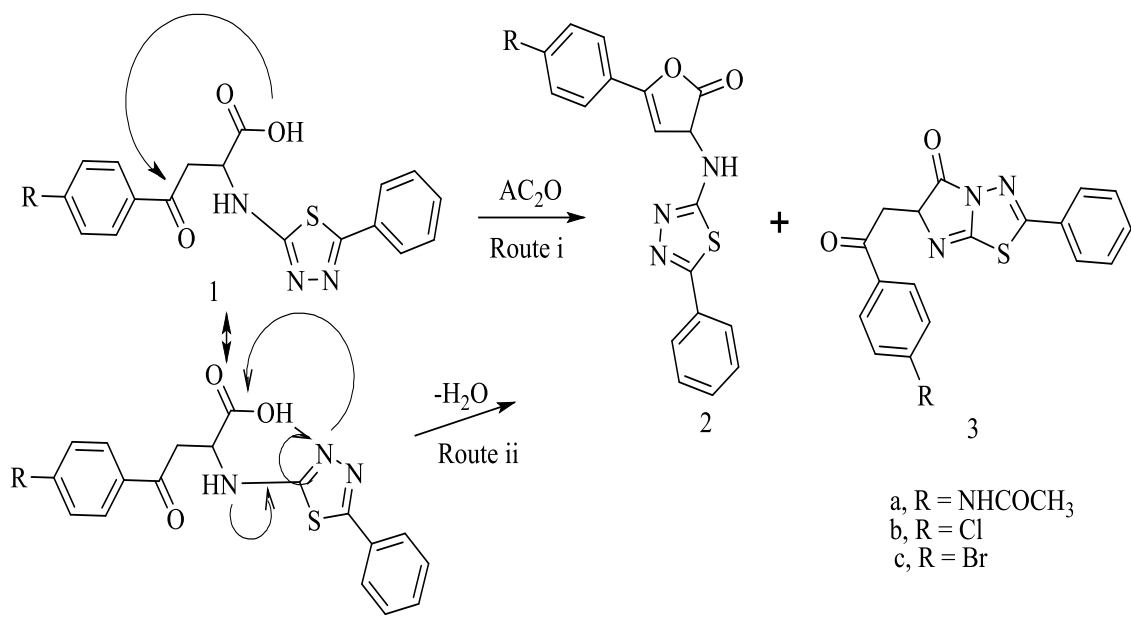

Scheme 2.
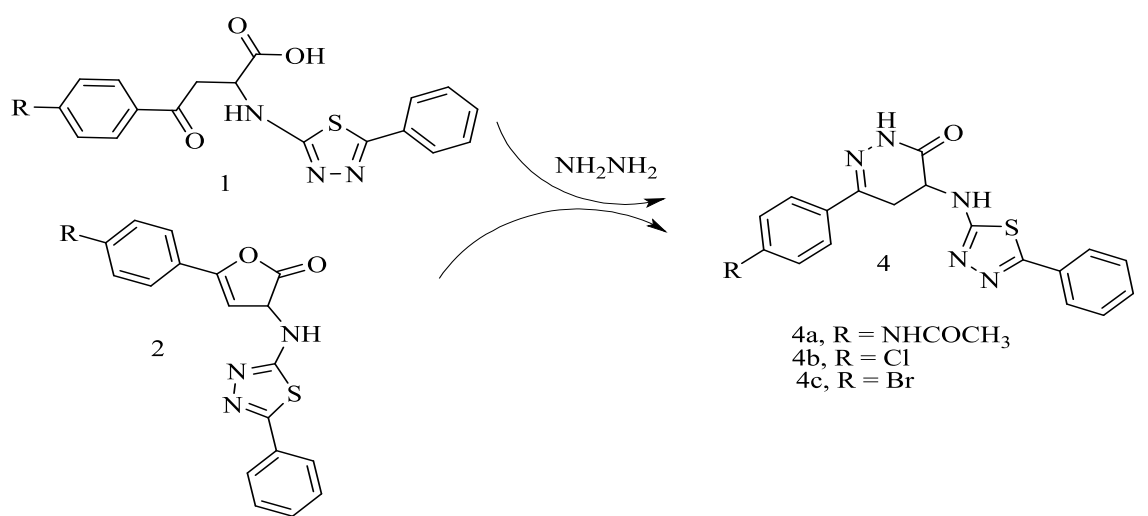

$4 \mathrm{a}, \mathrm{R}=\mathrm{NHCOCH}_{3}$

$4 \mathrm{c}, \mathrm{R}=\mathrm{Br}$

Scheme 3 .

where: $\mathrm{R}=\mathrm{NHCOCH}_{3}, \mathrm{~N}$-(4-(6-o xo-5-((5-phenyl-1,3,4-thiadiazo 1-2-yl)amino)1,4,5,6-tetrahydropyridazin- 3-yl)phenyl)acetamide (4a).

$\mathrm{R}=\mathrm{Cl}$, 6-(4-Chlorophenyl)-4-((5-phenyl-1,3,4-thiadiazol-2-yl)a mino)-4,5dihydropyridazin-3(2H)-one $(4 \mathrm{~b})$.

$\mathrm{R}=\mathrm{Br}$, 6-(4-Bromophenyl)-4-((5-phenyl-1,3,4-thiadiazol-2-yl)amino)-4,5dihydropyridazin-3(2H)-one $(4 \mathrm{c})$. 
Estimation of the synthesized compounds $(4 a-c)$ as antioxidants for base stock Effect of compounds 4 a-c on Total Acid Number (TAN) on base stock

The oxidation process of engine lubricants progressed by two mechanisms, namely oxidation and thermal decomposition. Mineral oil is very complex in nature due to the presence of large range of molecular types and functional groups. This complex structure makes the oxidation reactions extremely hard to understand. The test is carried out at $24,48,72$ and 96 hours. The results showed that the oxidative products (acidic, ketonic and alcoholic compounds) increased with time. Therefore, in the absence of antioxidants, the TAN values of the base stock increased from $0.07 \mathrm{mg} \mathrm{KOH} / \mathrm{g}$ to $2.02 \mathrm{mg} \mathrm{KOH} / \mathrm{g}$ after 96 . Also viscosity increased from 52.38 to $77.71 \mathrm{cSt}$, at $40^{\circ} \mathrm{C}$ (Table 3). Consequently, after adding the prepared antioxidants the efficiency of them as inhibitors is studied.

TABLE 3. Acid numbers (ANs) and viscosity of the base oil without antioxidants.

\begin{tabular}{|c|c|c|c|c|c|c|c|c|c|}
\hline \multicolumn{10}{|c|}{ Oxidation time interval (h) } \\
\hline \multicolumn{5}{|c|}{ Total Acid numbers, КОН mg /g Sample } & \multicolumn{5}{|c|}{ Viscosity (cst), at $40^{\circ} \mathrm{C}$} \\
\hline Blank & $24 \mathrm{~h}$ & $48 \mathrm{~h}$ & $72 \mathrm{~h}$ & $96 \mathrm{~h}$ & Blank & $24 \mathrm{~h}$ & $48 \mathrm{~h}$ & $72 \mathrm{~h}$ & $96 \mathrm{~h}$ \\
\hline 0.07 & 0.94 & 1.02 & 1.20 & 2.02 & 52.38 & 59.39 & 64.35 & 68.49 & 77.71 \\
\hline
\end{tabular}

Effect of additives concentration on TAN values

Three concentrations (200, 400, and $500 \mathrm{ppm})$ of each prepared antioxidant were added to the blank sample.

The results obtained in Table 4 illustrated the following:

- After $24 \mathrm{~h}$, by adding 200 ppm of antioxidant $4 \mathrm{a}$ to the blank sample, total acid number value decreased from 0.94 to $0.069 \mathrm{KOH} \mathrm{mg} / \mathrm{g}$. After $48 \mathrm{~h}$, the value decreased from 1.02 to $0.083 \mathrm{KOH} \mathrm{mg/g}$. A marked decrease is observed in the third day of oxidation $(72 \mathrm{~h}$ ), from 1.2 to $0.441 \mathrm{KOH}$ $\mathrm{mg} / \mathrm{g}$. Consequently, after $96 \mathrm{~h}$ the value decreased from 2.02 down to $0.778 \mathrm{KOH} \mathrm{mg} / \mathrm{g}$.

- In the case of blank with $400 \mathrm{ppm}$ of $4 \mathrm{a}$, the values of TAN decreased during the oxidation period $(24-96 \mathrm{~h})$ as follows: $(0.94-2.02$ down to $0.075-0.916 \mathrm{KOH} \mathrm{mg/g).}$

- Increasing concentration of 4 a to $500 \mathrm{ppm}$ gave the following results of the TAN values $(0.94-2.02$ down to $0.164-1.003 \mathrm{KOH} \mathrm{mg/g})$.

- Addition of $4 \mathrm{~b}$ to blank sample (200, 400 and $500 \mathrm{ppm})$ during the oxidation period illustrate the following:

a) With 200 ppm, TAN changed (from $0.94-2.02$ down to $0.082-0.936$ $\mathrm{KOH} \mathrm{mg} / \mathrm{g}$ ) respectively.

b) After adding $400 \mathrm{ppm}$ the values gradually changed from $(0.94-2.02$ down to $0.116-1.007 \mathrm{KOH} \mathrm{mg} / \mathrm{g}$ ) respectively.

Egypt. J. Chem. 60, No.1 (2017) 
c) The effect of adding $500 \mathrm{ppm}$ of $4 \mathrm{~b}$ on the plank sample decreases the TAN by the following values, (from $0.94-2.02$ down to $0.235-1.260$ $\mathrm{KOH} \mathrm{mg} / \mathrm{g}$ ) respectively.

- Finally, by studying the effect of antioxidant 4c (200, 400 and 500 ppm) on the blank sample during the oxidation time interval we noticed that:

a) With 200 ppm, TAN changed (from $0.94-2.02$ down to $0.109-0.968$ $\mathrm{KOH} \mathrm{mg} / \mathrm{g}$ ) respectively.

b) With increasing concentration up to $400 \mathrm{ppm}$, the values have changed, (from $0.94-2.02$ down to $0.152-1.201 \mathrm{KOH} \mathrm{mg} / \mathrm{g}$ ) respectively.

c) At last, after adding $500 \mathrm{ppm}$ of $4 \mathrm{c}$, the values changed from $0.94-2.02$ down to $0.246-1.343 \mathrm{KOH} \mathrm{mg} / \mathrm{g}$ during the time interval respectively.

Effect of electron donating and withdrawing groups

As it is clear from Scheme 3, the data shown in Table 4, we noticed that the most effective substituted groups are shown with donating group (4a) than withdrawing groups ( $4 \mathrm{~b}$ and $4 \mathrm{c}$ ) This may be attributed to the electron donating nature group (4a) that facilitates the break of the hydrogen-bonded to the nitrogen to produce a stable free radical but in case of electron withdrawing groups $(4 \mathrm{~b}, 4 \mathrm{c})$ that may increase the difficulty of the $\mathrm{N}-\mathrm{H}$ bond breaking whereby it has a much lower oxidation stability.

TABLE 4. Variation of TAN with oxidation time at changed additive concentrations .

\begin{tabular}{|c|c|c|c|c|c|}
\hline \multirow{3}{*}{ Compound } & \multicolumn{5}{|c|}{ Total Acid number, KOH mg / g Sample } \\
\cline { 2 - 6 } & $\begin{array}{c}\text { Concentration } \\
(\mathbf{p p m})\end{array}$ & \multicolumn{4}{c|}{ Time (h) } \\
\cline { 2 - 6 } & 200 & $\mathbf{2 4}$ & $\mathbf{4 8}$ & $\mathbf{7 2}$ & $\mathbf{9 6}$ \\
\hline \multirow{3}{*}{$4 \mathrm{a}$} & 400 & 0.069 & 0.083 & 0.441 & 0.778 \\
\cline { 2 - 6 } & 500 & 0.164 & 0.246 & 0.756 & 1.003 \\
\cline { 2 - 6 } & 200 & 0.082 & 0.138 & 0.532 & 0.936 \\
\hline \multirow{3}{*}{$4 \mathrm{~b}$} & 400 & 0.116 & 0.172 & 0.698 & 1.007 \\
\cline { 2 - 6 } & 500 & 0.235 & 0.361 & 0.799 & 1.260 \\
\hline \multirow{3}{*}{$4 \mathrm{c}$} & 200 & 0.109 & 0.195 & 0.586 & 0.968 \\
\cline { 2 - 6 } & 400 & 0.152 & 0.236 & 0.739 & 1.201 \\
\cline { 2 - 6 } & 500 & 0.246 & 0.404 & 0.854 & 1.343 \\
\hline
\end{tabular}

The data showed in Fig. 1, 2 and 3 represented the correlation between the oxidation periods and TAN of blank sample without and with additive concentrations of 200, 400 and $500 \mathrm{ppm}$, for compounds $4 \mathrm{a}, 4 \mathrm{~b}$ and $4 \mathrm{c}$, respectively. The order of increasing inhibition efficiency is ranked as follows: 
$4 a>4 b>4 c>$ blank. Thence, increasing the additive concentration from 200 to $500 \mathrm{ppm}$ lead to an increase in the TAN values. This may be attributed to high sulphurpercent which retard the inhibition efficiency [32]

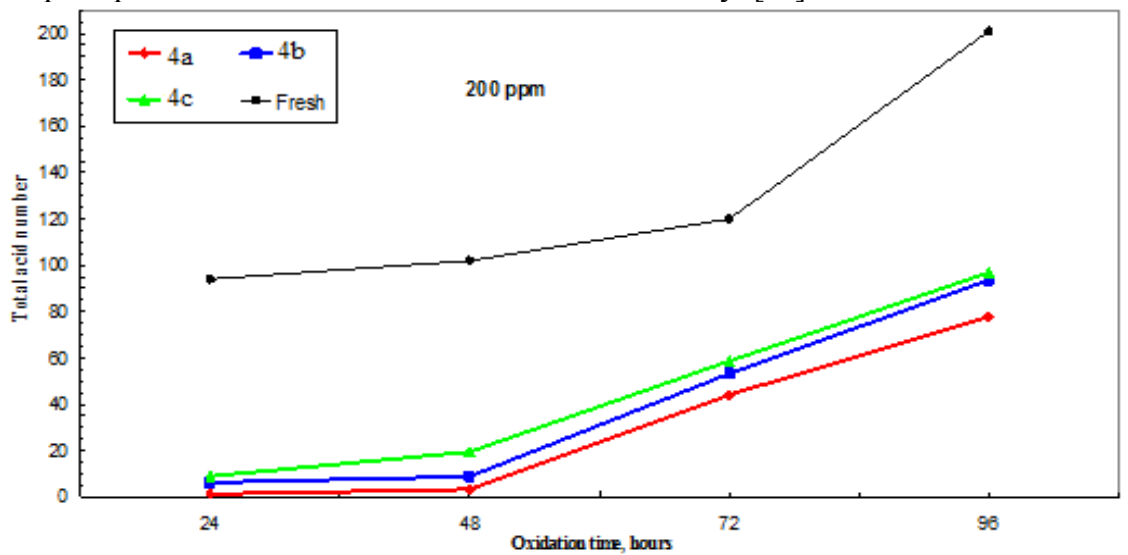

Fig.1. TAN variation of the base stock without and with $200 \mathrm{ppm}$ of $4 \mathrm{a}, 4 \mathrm{~b}$ and $4 \mathrm{c}$.

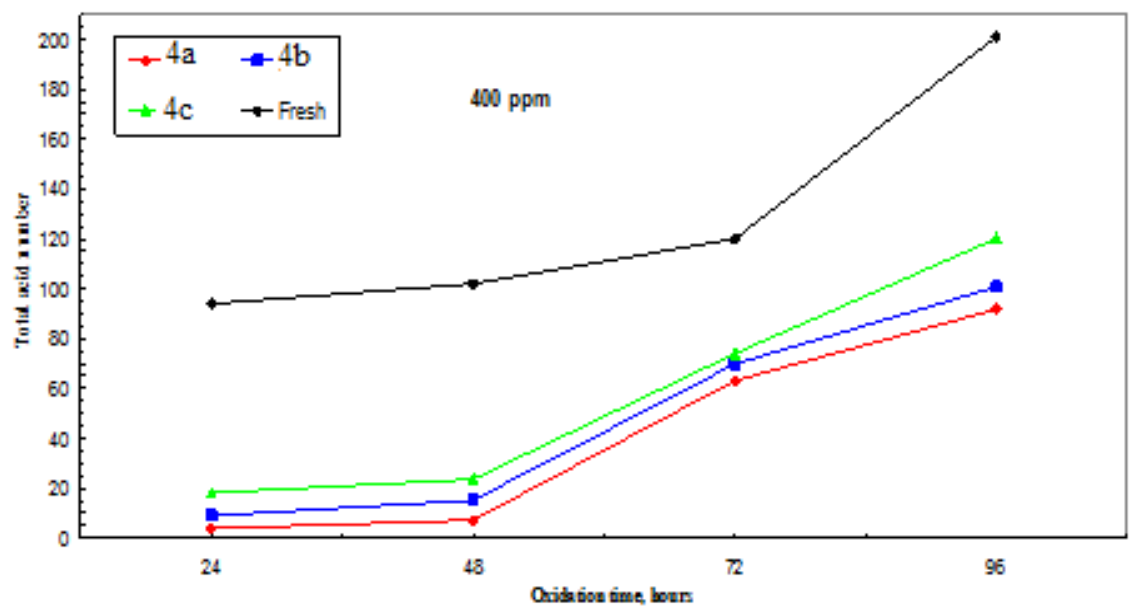

Fig. 2. TAN variation of the base stock without and with $400 \mathrm{ppm}$ of $4 \mathrm{a}, 4 \mathrm{~b}$ and $4 \mathrm{c}$. 


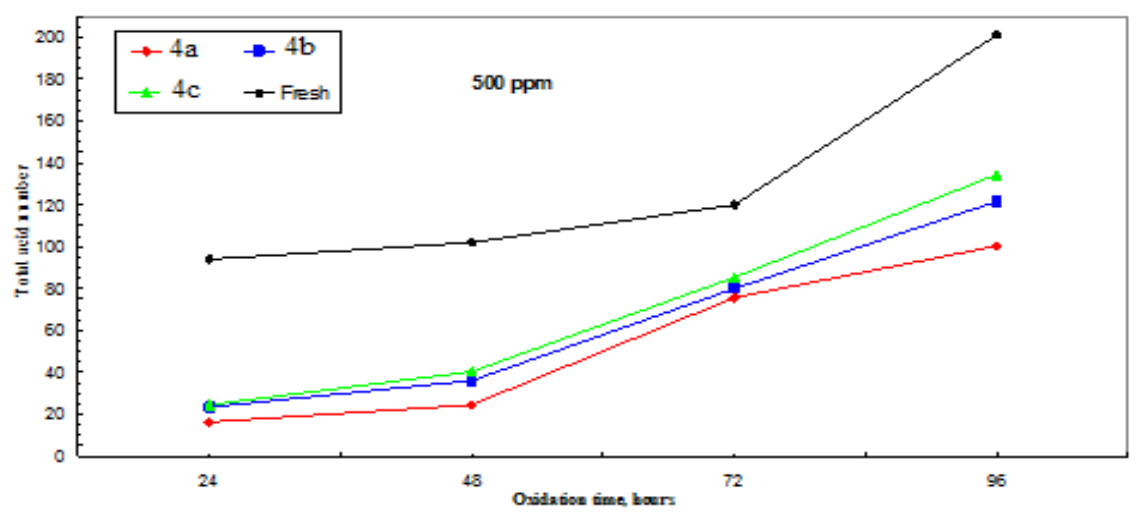

Fig. 3. TAN variation of the base stock without and with $500 \mathrm{ppm}$ of $4 \mathrm{a}, 4 \mathrm{~b}$ and $4 \mathrm{c}$.

Effect of antioxidants on viscosity of blank sample

The most important physical properties for the categorization of base stock is Viscosity. As the oxidative products increased lead to the formation of sludge and other higher molecular weight compounds so causing the increasing in viscosity. The data shown in Table 3 obtained that the viscosity of the blank sample increased from 52.38 up to $77.71 \mathrm{cSt}$ after oxidation for 24 to 96 hours. The data of the viscosity values are tabulated in Table 5 and graphically represented in Fig. $4-6$, the results of the viscosities are given after oxidation time intervals for $(24,48,72$ and 96 hours). The viscosity decreased by increasing the additive concentration from $200 \mathrm{ppm}$ up to $500 \mathrm{ppm}$. Among the three base compounds ( $4 \mathrm{a}, 4 \mathrm{~b}$ and $4 \mathrm{c}$ ), the order of these compounds towards decreasing viscosity is ranked as follows $4 a>4 b>4 c$.

Correlation of the antioxidants activity with their structures

The program $\mathrm{Ab}$ in itio $(\mathrm{HF} / 3-21 \mathrm{G})$ can be used for correlation between the structure of the prepared compounds and their antioxidant activity. The more values of the $\mathrm{E}_{\text {Номо }}$ simplify adsorption and then restraint by the effect of transported process through the adsorbed layer. Low energy gap $(\Delta \mathrm{E})$ gives good antioxidant efficiencies . The results of the calculations, for the synthesized compounds $4 \mathrm{a}, 4 \mathrm{~b}$ and $4 \mathrm{c}$ are given in Table 6 . The results obtained by $\mathrm{Ab}$ initio $\mathrm{HF} / 3-21 \mathrm{G}$ method showed that $(4 \mathrm{a} ; \Delta \mathrm{E}=4.963),(4 \mathrm{~b} ; \Delta \mathrm{E}=5.304),(4 \mathrm{c} ; \Delta \mathrm{E}=$ 5.344). According to these values, the efficiency order is as follows $4 \mathrm{a}>4 \mathrm{~b}>4 \mathrm{c}$. The HF/3-21G calculations agreed with the experimental data. 
TABLE 5. Variation of viscosity with oxidation time and different additive concentrations.

\begin{tabular}{|c|c|c|c|c|c|}
\hline \multirow{3}{*}{ Compound } & \multicolumn{5}{|c|}{ Viscosity, cst at $40^{\circ} \mathrm{C} \times 10^{2}$} \\
\hline & \multirow{2}{*}{$\begin{array}{c}\text { Concentration } \\
\text { (ppm) }\end{array}$} & \multicolumn{4}{|c|}{$\begin{array}{c}\text { Oxidation time } \\
\text { (hr) }\end{array}$} \\
\hline & & 24 & 48 & 72 & 96 \\
\hline \multirow{3}{*}{$4 a$} & 200 & 5239 & 5243 & 5370 & 5736 \\
\hline & 400 & 5242 & 5247 & 5702 & 6011 \\
\hline & 500 & 5253 & 5264 & 5722 & 6075 \\
\hline \multirow{3}{*}{$4 \mathrm{~b}$} & 200 & 5245 & 5263 & 5854 & 6013 \\
\hline & 400 & 5257 & 5298 & 5988 & 6032 \\
\hline & 500 & 5266 & 5314 & 6018 & 6154 \\
\hline \multirow{3}{*}{$4 \mathrm{c}$} & 200 & 5251 & 5272 & 5901 & 6025 \\
\hline & 400 & 5268 & 5321 & 6035 & 6121 \\
\hline & 500 & 5278 & 5333 & 6066 & 6371 \\
\hline
\end{tabular}

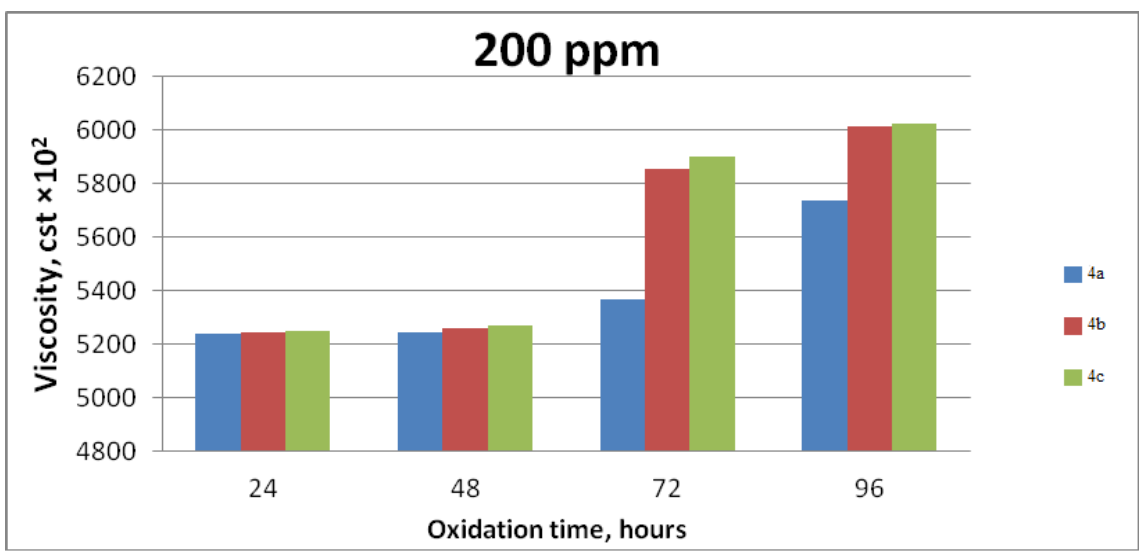

Fig. 4. Variation of viscosity of the base oil with $200 \mathrm{ppm}$ of antioxidants $4 \mathrm{a}, 4 \mathrm{~b}$ and $4 \mathrm{c}$. 


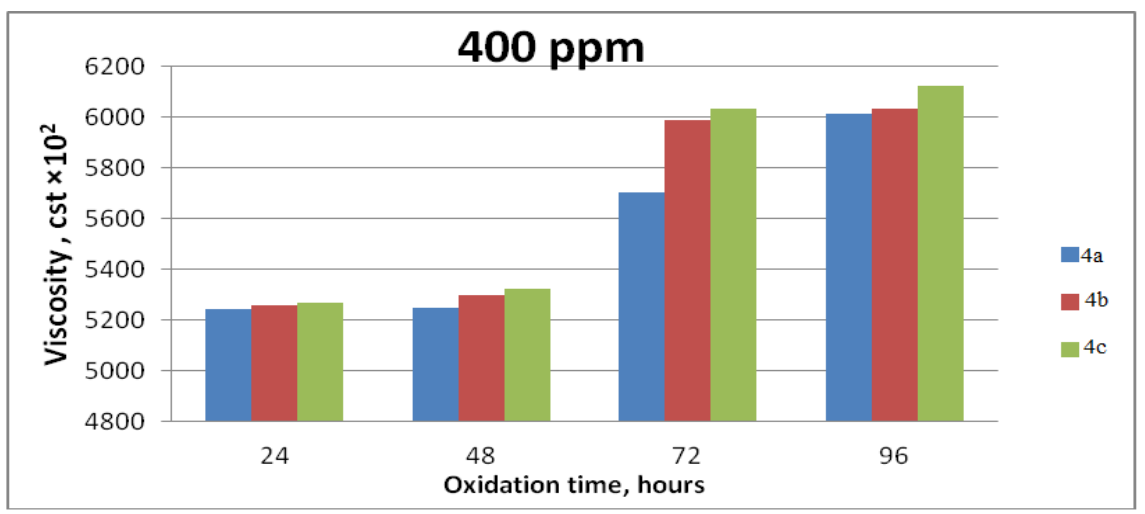

Fig. 5. Variation of viscosity of the base oil with $400 \mathrm{pm}$ of antioxidants $4 \mathrm{a}, 4 \mathrm{~b}$ and $4 \mathrm{c}$.

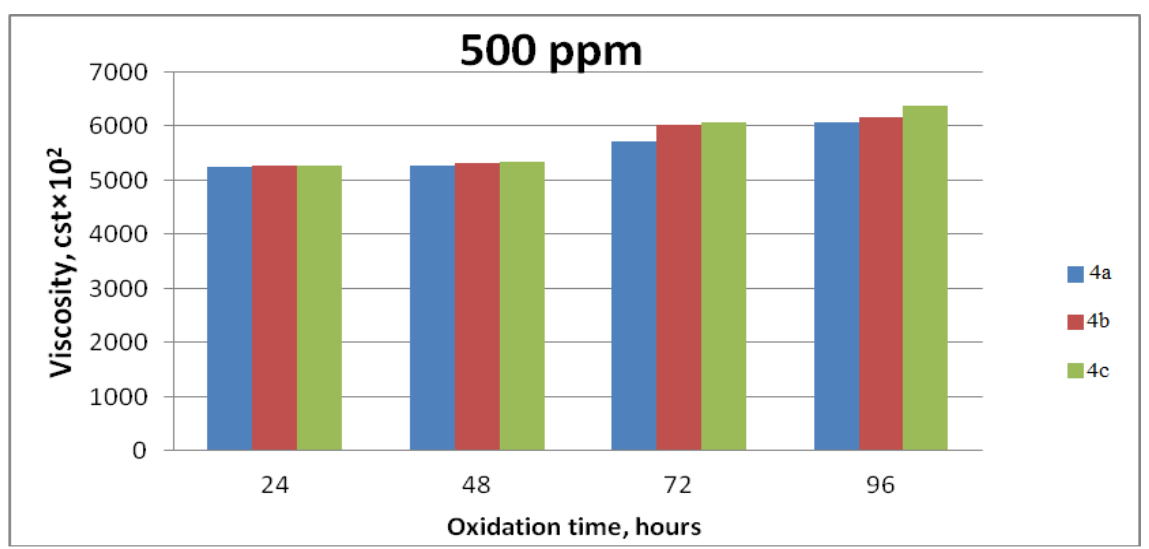

Fig. 6. Variation of viscosity of the base oil with $500 \mathrm{ppm}$ of antioxidants $4 \mathrm{a}, 4 \mathrm{~b}$ and $4 \mathrm{c}$.

TABLE 6. Quantum Chemical Parameters.

\begin{tabular}{|c|c|c|c|c|c|}
\hline \multirow{2}{*}{ Compound } & \multicolumn{5}{|c|}{ Quantum Parameters } \\
\cline { 2 - 6 } & $\begin{array}{c}\text { Dipole } \\
\text { Moment } \\
\text { (Debye) }\end{array}$ & $\begin{array}{c}\text { Total energy } \\
\text { (Kcal/mole) }\end{array}$ & $\begin{array}{c}\mathbf{E}_{\text {LUMO }} \\
\mathbf{e V}\end{array}$ & $\begin{array}{c}\mathbf{E}_{\text {HOMO }} \\
\mathbf{e V}\end{array}$ & $\begin{array}{c}\Delta \mathbf{E} \mathbf{e V} \\
\mathbf{E}_{\text {LUMO }} \\
\mathbf{E}_{\text {HOMO }}\end{array}$ \\
\hline \multicolumn{5}{|c|}{ Ab Initio HF/3-21G } \\
\hline 4a & 3.11 & 7.736 & -2.924 & -7884 & 4.963 \\
\hline $4 \mathrm{~b}$ & 3.74 & 12.548 & -2.594 & -7898 & 5.304 \\
\hline 4c & 3.36 & 12.384 & -2.595 & -7.939 & 5.344 \\
\hline
\end{tabular}

Evaluation of the synthesized compounds as corrosion inhibitors for carbon steel in acid medium

Potentiodynamic polarization measurements are performed for carbon steel immersed in $1 \mathrm{M} \mathrm{HCl}$ in absence and presence of the synthesized compounds to evaluate their effectiveness as corrosion inhibitors. From Table 7 and Fig. 7, the

Egypt. J. Chem. 60, No. 1 (2017) 
efficiency order of these compounds towards corrosion inhibition is ranked as follows: $4 \mathrm{a}>4 \mathrm{~b}>4 \mathrm{c}$ with value $76.1>68.8>56.0 \%$, respectively and the Data reveal the following:

1- Addition of any of the three compounds resulted in a significant reduction in the corrosion current density $\left(I_{\text {corr }}\right)$ in comparis on to that measured in the blank acid solution. On increasing the concentration of these inhibitors, $I_{\text {corr }}$ decreases continuously indicating that their molecules adsorb on Carbon steel surface forming a physical barrier against the corrosion attack via blocking the active sites on the steel surface[33].

The maximum displacement in $E_{\text {corr }}$ measured in the presence of corrosion inhibitors, with respect to that measured in the blank acid solution, is $+99,+46$, $+31 \mathrm{mV}$ for $4 \mathrm{a}, 4 \mathrm{~b}$ and $4 \mathrm{c}$, respectively. According to Riggs [34] an inhibitor can be classified as anodic or cathodic-type inhibitor if the $E_{\text {corr }}$ displacement is at least $\pm 85 \mathrm{mV}$ relative to the value of $E_{\text {corr }}$ measured for the blank solution. Therefore, $4 \mathrm{a}$ can act as anodic-type inhibitor while $4 \mathrm{~b}$ and $4 \mathrm{c}$ act as mixed-type inhibitors with major effectiveness on anodic reactions. This behavior supports the adsorption of inhibitor onto the metal surface and caused a barrier effect for mass and charge transfer of anodic and cathodic reactions [35].

TABLE 7. Electrochemical polarization parameters for the corrosion of carbon steel in $1 \mathrm{M} \mathrm{HCl}$ containing various concentrations of the investigated inhibitors.

\begin{tabular}{|c|c|c|c|c|}
\hline Inhibitor & $\begin{array}{c}\text { Concentration (mmol } \\
\mathbf{d m - 3})\end{array}$ & $\begin{array}{c}\text {-Ecorr }(\mathbf{m V} \text { vs. } \\
\text { S CE) }\end{array}$ & $\begin{array}{c}\text { Icorr } \mathbf{( m A} \mathbf{~ c m}- \\
\mathbf{2})\end{array}$ & $\begin{array}{c}\mathbf{\eta p} \\
\mathbf{( \% )}\end{array}$ \\
\hline Blank & 0 & 558 & 1.2235 & -- \\
\hline \multirow{3}{*}{$4 \mathrm{a}$} & 0.025 & 480 & 0.3618 & 70.4 \\
\cline { 2 - 5 } & 0.050 & 459 & 0.3507 & 71.3 \\
\cline { 2 - 5 } & 0.075 & 504 & 0.2926 & 76.1 \\
\hline \multirow{3}{*}{$4 \mathrm{~b}$} & 0.025 & 562 & 0.4590 & 62.5 \\
\cline { 2 - 5 } & 0.050 & 512 & 0.4216 & 65.5 \\
\cline { 2 - 5 } & 0.075 & 528 & 0.4067 & 68.8 \\
\hline \multirow{3}{*}{$4 \mathrm{c}$} & 0.025 & 553 & 0.7639 & 37.6 \\
\cline { 2 - 5 } & 0.050 & 527 & 0.5581 & 54.4 \\
\cline { 2 - 5 } & 0.075 & 544 & 0.5383 & 56.0 \\
\hline
\end{tabular}




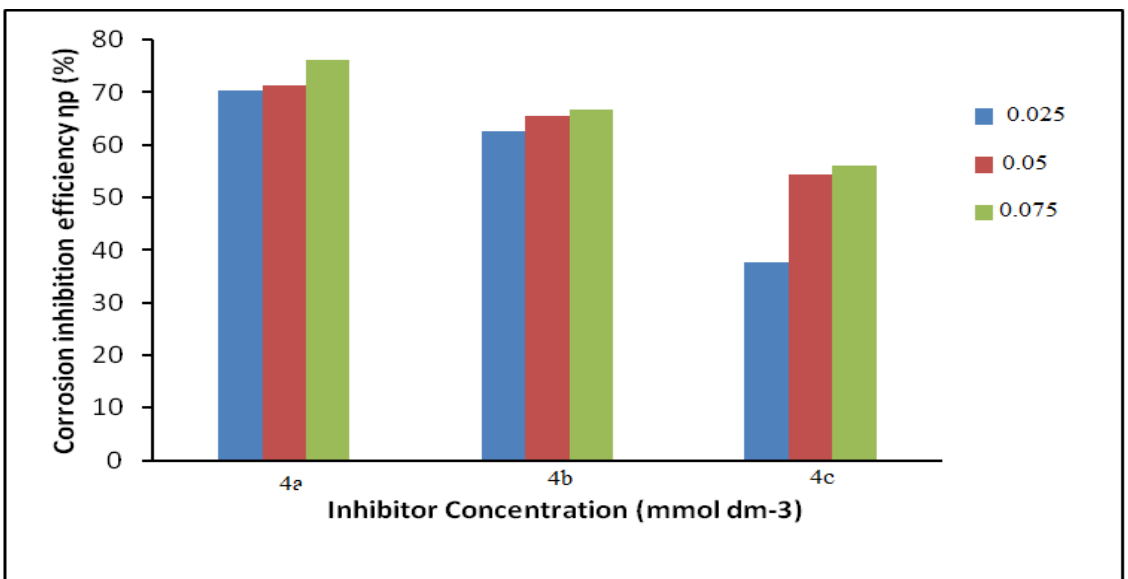

Fig.7. Relationship between corrosion inhibition efficiency (१p, \%) and different concentrations of the investigatedinhibitors in $1 \mathrm{M} \mathrm{HCl}$.

\section{Conclusion}

The newly prepared compounds were examined as antioxidant and anticorrosion the compounds $4 \mathrm{a}$, $4 \mathrm{~b}$ (high $\mathrm{E}_{\mathrm{HOMO}}$ ) were showed high antioxidant activities and anticorrosion. There are relationships between anticorrosion and antioxidant agents from point of view quantum chemical parameter. Increasing in the $\mathrm{E}_{\mathrm{HOMO}}$ values refer to high antioxidant activity that was identical to identical to the experimental results.

\section{References}

1. Ohgake, R., Sunami M., Yoshida T., and Watanabe H., ASTM Spec. Tech. Publi, No. 1021, 32 (1989).

2. Sumittra, D.P. Amorn Tribology Internat., 44(3), 266 (2011).

3. Migdal, C.A. "Lubric. Addi. Chem. Applica." NY: Marcel Dekker Inc; p $1-23$ (2003).

4. Troyer, D. and Fitch J. Oil Anal Basic, $1^{\text {st }}$ ed. Chippenharm: Coxmoor Publi. (2003).

5. Bhatlacharya A., Singh, T., Verma, V.K. and Nakagama K., Wear, 136, 345 (1990).

6. Huang, W. J., Wu, X. H. and Zeng Y., J. Synth. Lubrication, 21(3), 231 (2004).

7. Hassan, H. M., Amer F. A., Moawad, E. B. and Shaker N., Lubrication Sci., 22, 163 (2010). 
8. El Sayed, E., Esam E., Nadjet, R., Hamdy, H.A., Wedad, M.A. and Yasser, M. B., J. Saudi Chemical Society 18, 443 (2014).

9. EL-Hashash, M. A., Rizk, S. A., Shaker S. A., and Mostafa, K.K., Egypt. J. Chem., 55, 1 (2012).

10. El-Hashash, M. A. , Rizk, S. A., and Atta-Alla, S.R., Molecules, 20, 22069 (2015).

11. Rizk S. A., Amer. J. Chem., 1, 66 (2011),DOI: 10. 5923/j.chemistry.20110101.01

12. El-Hashash M. A., and Rizk, S. A., Eur. Chem. Bull., 2(9), 637 (2013).

13. El-Hashash M.A. and S.A. Rizk, J. heterocycl. Chem., 53, 32 (2015).

14. El-Hashash, M. A. and Rizk, S. A., E. J. Chem., 54, 3 (2011).

15. El-Hashash M.A. and Rizk S.A., Inter J Chem Petrochem Tech (IJCPT), 3, 1 (2013).

16. El-Hashash M.A., Rizk S.A. and Nessim M. I., Chem. Eng. Pro. Tech (CEPT), 4(6), (2013).

17. K. Toshikazu, Food Ingred. J. Japan, 206 (2002).

18. D. Barrett, A. Tanaka, K. Harada, H. Ohki, E. Watabe, K. and Maki, F. Ikeda, Bioorg. Med. Chem. Lett., 11, 479 (2001).

19. J. T. Kovalainen, J. A. M. Christains, S. Kotisaati, J. T. Laitinen and P. T. Mannisto, J. Med. Chem., 42, 1193 (1999).

20. P. Cotelle, N. Cotelle, E. Teissier and H. Vezin, Bioorg. Med. Chem. 11, 1087 (2003).

21. V., Weber, P. Coudert, C. Rubat, E. Duroux, J.C. Vallee-Gramain, J. Couquelet and M. Madesclaire, Bioorg. Med. Chem. 10, 1647 (2002).

22. V. Weber, P. Coudert, C. Rubat, E. Duroux and F. Leal, J. Couquelet, J. Pharm. Pharmacol., 52, 523 (2000).

23. S. Manfredini, S. Vertuani, B. Manfredi, G. Rossini, G. Calviello and P. Palozza, Bioorg. Med. Chem. 8, 2791 (2000).

24. T. Mashino, Y. Takigawa, N. Saito, L. Q. Wong and M. Mochizuki, Bio org. Med. Chem. Lett., 10, 2783 (2000).

25. Hergold-Brundic, A., Nagl A., Balzarini, J., Yong-Jin, Y., In-S un, K., and Park ,J. K., Bull. Kor Chem. Soc., 28, 8 (2007).

26. Piaz, V.D., Vergelli, C., Giovannoni, M.P., Scheideler, M.A., Petrane, G., and Zaratin, P., Farmaco, 58, 1063 (2003).

27. Horino H., Mimura T., Kagechika K., Ohta M., Kubo H. and Kitagawa M., Chem. Pharm.Bull. 46, 402 (1998). 
28. Yamamoto, A., Iwama, T., Takeda, H. and Nagai, H., Jpn. J. Pharmcol, 68, 47 (1995).

29. Tsubaki, K., Taniguchi, K., Tabuchi, S., Okitsu, O., Hahori, K., Soki, J., Sakane, K. and Tanaka, H., Bioorg.Med.Chem.Lett. 12, 2787 (2000).

30. Robert Allcock, W. , Jiang, H., Z., Johnston, K. A., Morgan, K. M., Rosair, G. M., Iwase, K., Kohno, Y. and Adam, D. R., Bioorg. \& Med . Chem. Lett. 21, 3307 (2011).

31. Kesharwani, K., Sahu, N.K. and Kohli ,D. V., J. pharma,Chem. 43, 6 (2009).

32. Nessim, M.I., Osman, D.I., Attia E.K., Ahmed E.A. and Mohammed H.A., Int. J. Curr.Res.Chem. Pharma. Sci. 2(2), 80-93 (2015).

33. Faustin, M., Maciuk, A., Salvin, P., Roos, C. and Lebrini, M., Corrosion inhibition of $\mathrm{C} 38$ steel by alkaloids extract of Geissospermum laeve in $1 \mathrm{M}$ hydrochloric acid: Electrochemical and phytochemical studies. Corros. Sci., 92, 287-300 (2015).

34. Riggs Jr., O.L. Corrosion Inhibitors, $2^{\text {nd }}$ ed., C.C. Nathan, Houston, TX, (1973).

35. Ahmed M. Al-Sabagh A., Notaila M. Nasser A., Ahmed A. Farag B., Mohamed A. Migahed B., Abdelmonem M.F. Eissa C., Tahany Mahmoud A. Egyptian Journal of Petroleum 22, 101-116 (2013).

Received 16/2/2017; accepted 29/3/2017)

$$
\begin{aligned}
& \text { توليف وتطيقات بيريدازينونات لتحسين خواص الزيوت الاساسية } \\
& \text { سامح رزق' ، سيد عطية' ، دعاء عثمان و ماهز ابرهيم نسيمج } \\
& \text { 'قسم الكيمياء ـكلية العلوم- جامعة عين شمس و بمعهد بحوث البترولـ القاهرة - مصر. }
\end{aligned}
$$

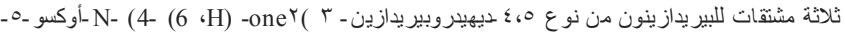

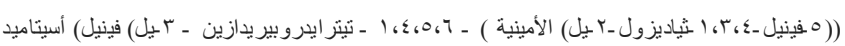

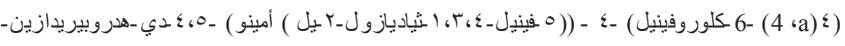

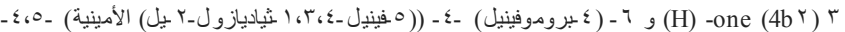

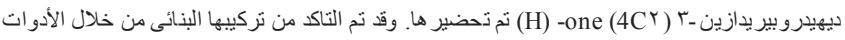

التقليدية للتحليل، التحليل العذصري، الأشعة تحت الدمراء و الرنين المغناطبسى الهيدروجينى. وأكدت

أدوات التحليل المركبات الثلاثة المخلقة. هذه المركبات الاروماتية غير الدتجانسة مستقرة كميبائيا ولها

خو اص متعددة لتحسين مواصفات زيوت التزييت الاساسية. لقد تم اختبارها كمضادات الأكسدة للزيت

المحلي من خلال التغيير في عدد الحمض الكلي (تان). وقد أظهرت نتائج جيدة كمضادات الأكسدة لزيت

الأساس. كما تم اختبار هذه المركبات الثلاثة كثبطات تأكل للصلب الكربوني في وسط حامضى. و قد تم

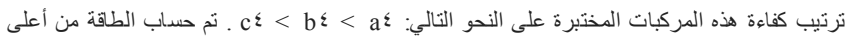

الدار الجزيئي الدحتل (هومو) وأقل المداري الجزيئية غير المأهولة (لومو) للمركبات المحضرة الثناثة

عبر طريقة أب إنيشيو. و أظهرت دراسة الحسابات الكيمائية الكيمياوية للمركبات المركبة تطابقا جيدا مع

Egypt. J. Chem. 60, No. 1 (2017)

$$
\text { النتائج التجريبية. }
$$

